\title{
ANALISIS FLYPAPER EFFECT PADA DANA ALOKASI UMUM DAN PENDAPATAN ASLI DAERAH TERHADAP BELANJA DAERAH DI PROVINSI ACEH \\ Yani Rizal $^{a}$, Safuridar ${ }^{b}$, Muhammad Ayub Siregar $^{c *}$ \\ ${ }_{a, b, c}$ Universitas Samudra Langsa \\ $c^{*}$ Email : muhammadayubsiregar06@gmail.com
}

\begin{abstract}
Abstrak
Penelitian ini dilakukan dengan tujuan untuk mengetahui besarnya pengaruh DAU dan PAD terhadap Belanja Daerah dan apakah terjadi Flypaper Effect pada Belanja Daerah di Provinsi Aceh. Data yang digunakan adalah data sekunder yang bersumber dari Badan Pusat Statistik (BPS). Data yang diperoleh dianalisis menggunakan persamaan regresi linier berganda, uji $t$, uji $F$ dan Koefisien determinasi $\left(R^{2}\right)$. Hasil penelitian diperoleh persamaan $Y=3,88+2,0463 \log X 1+$ 3,1499logX2. Nilai konstanta sebesar 3,88 artinya apabila nilai DAU dan PAD tidak mengalami perubahan, maka Belanja Daerah Provinsi Aceh sebesar 3,88 satuan. Nilai koefisien DAU sebesar 2,0463 berpengaruh positif dan signifikan terhadap Belanja Daerah. Nilai koefisien PAD sebesar 3,1499 berpengaruh positif dan signifikan terhadap Belanja Daerah. Koefisien determinasi $\left(R^{2}\right)$ adalah 0,9783 atau sama dengan $97,83 \%$. Sedangkan sisanya 2,17\% dijelaskan oleh variabel lain yang tidak diteliti. Hasil analisis Flypaper Effect: koefisien DAU sebesar 2,0463 lebih besar dari koefisien PAD sebesar 3,1499 dimana memiliki arti bahwa tidak terjadi flypaper effect pada Belanja Daerah di Provinsi Aceh.
\end{abstract}

Kata Kunci : Flypaper Effect, Dana Alokasi Umum, Pendapatan Asli Daerah, Belanja Daerah.

\begin{abstract}
This study was conducted with the aim of knowing the magnitude of the influence of $D A U$ and PAD on Regional Expenditures and whether there is a Flypaper Effect on Regional Expenditures in Aceh Province. The data used is secondary data sourced from the Central Statistics Agency (BPS). The data obtained were analyzed using multiple linear regression equations, $t$ test, $F$ test and the coefficient of determination $(R 2)$. The results obtained by the equation $Y=3,88+2,0463 \log X 1+3,1499 \log X 2$. The constant value of 3,88 means that if the value of DAU and PAD does not change, then the Regional Expenditure of Aceh Province is 3,88 units. The coefficient value of the General Allocation Fund of 2,0463 has a positive and significant effect on Regional Expenditures. The coefficient value of Regional Original Income of 3,1499 has a positive and significant effect on Regional Expenditures. The coefficient of determination ( $R 2)$ is 0,9783 or equal to $97,83 \%$. While the remaining $2,17 \%$ is explained by other variables not examined. The results of the Flypaper Effect analysis: the General Allocation Fund coefficient of 2,0463 is greater than the coefficient of Local Original Income of 3,1499 which means that there is no flypaper effect on Regional Expenditures in Aceh Province.
\end{abstract}

Keywords: Flypaper Effect, General Allocation Fund, Regional Original Income, Regional Expenditure. 


\section{PENDAHULUAN}

Indonesia merupakan suatu negara yang menganut sistem Otonomi Daerah dalam pelaksanaan pemerintahannya. Dalam Undang-Undang Nomor 23 tahun 2014 tentang Pemerintah Daerah sudah dijelaskan bahwa Otonomi Daerah merupakan hak, wewenang, dan kewajiban suatu daerah otonom untuk mengatur sendiri urusan pemerintah dan kepentingan masyarakat daerah setempat sesuai dengan peraturan perundang-undangan. Otonomi daerah memberikan kesempatan kepada masing-masing daerah untuk dapat mendorong partisipasi masyarakat di daerahnya tersebut untuk meningkatkan kinerjanya dalam rangka mewujudkan suatu kemandirian daerah. Pemerintah Indonesia mulai melaksanakan kebijakan tentang Otonomi Daerah secara efektif pada tangggal 1 Januari 2001. Pelaksanaan kebijakan tentang Otonomi Daerah dinilai sangat demokratis dan memenuhi aspek desentralisasi pemerintah yang sesungguhnya.

Setiap daerah di Indonesia memiliki perbedaan potensi, kebutuhan daerah dan sumber daya serta beban fungsi antar tingkat pemerintahan (Khoiri, 2015). Keadaan ini menimbulkan ketimpangan fiskal antara suatu daerah dengan daerah lainnya. Untuk menyeimbangkan ketimpangan fiskal ini pemerintah mengalokasikan dana transfer yang bersumber dari APBN untuk mendanai kebutuhan daerah dalam pelaksanaan desentralisasi. Dalam Undang-Undang Nomor 32 Tahun 2004 disebutkan bahwa untuk pelaksanaan kewenangan pemerintah daerah, pemerintah pusat akan mengalokasikan Dana Perimbangan yaitu Dana Alokasi Umum (DAU), Dana Alokasi Khusus (DAK), dan bagian daerah dari Dana Bagi Hasil (DBH) yang terdiri dari Pajak dan Sumber daya alam. Disamping dana perimbangan itu, pemerintah daerah mempunyai sumber pendanaan sendiri yang bersumber dari kekayaan daerah berupa Pendapatan Asli Daerah (PAD), pembiayaan, dan lain-lain pendapatan yang sah. Kebijakan penggunaan dana tersebut menjadi hak pemerintah daerah.

Menurut Ida, dkk (2012) Pendapatan Asli Daerah idealnya merupakan sumber pendapatan pokok daerah, sedangkan sumber pendapatan lain dapat bersifat fluktuatif dan cenderung diluar pengendalian kewenangan daerah. Pemerintah daerah diharapkan dapat meningkatkan PAD dengan tetap memperhatikan beberapa aspek seperti aspek efisiensi, ekonomis, dan netralitas. Dalam kenyataannya, dana yang dialokasikan dari pemerintah pusat ke pemerintah daerah di jadikan sumber dana utama untuk membiayai kebutuhan daerah.

Kuncoro (2007) menyebutkan bahwa PAD hanya mampu membiayai belanja pemerintah daerah paling besar 20\%. Hal ini menunjukkan bahwa muncul ketergantungan pemerintah daerah terhadap pemerintah pusat. Ketergantungan ini terlihat jelas dari aspek keuangan. Alokasi transfer Dana Alokasi Umum (DAU) yang diberikan pemerintah pusat kepada pemerintah daerah lebih tinggi dan kurang memperhatikan kemampuan daerah dalam mengoptimalkan sumber-sumber pendanaannya. Akibatnya pemerintah daerah akan selalu bergantungan dan menuntut transfer yang besar dari pemerintah pusat, bukannya memaksimalkan sumber kekayaan daerahnya tersebut. Permasalahan yang muncul akibat ketergantungan pemerintah daerah kepada dana transfer dari pemerintah pusat tersebut memicu terjadinya fenomena flypaper effect pada keuangan pemerintah daerah (Putra dan Dwirandra, 2015).

Akibatnya, menurut Oates (dalam Purnomo, 2011) dari tahun ke tahun pemerintah daerah selalu menuntut transfer yang lebih besar lagi dari pusat, bukannya mengeksplorasi 
basis pajak lokal secara lebih optimal. Berikut ini merupakan ringkasan anggaran dan realisasi Belanja Daerah Pemerintah Provinsi Aceh tahun 2013 sampai 2019.

Tabel 1. Anggaran dan Realisasi Belanja Daerah Pemerintah Provinsi Aceh Tahun 2013-2019

\begin{tabular}{cccc}
\hline Tahun & Anggaran (Rupiah) & Realisasi (Rupiah) & Perkembangan (\%) \\
\hline 2013 & 10.471 .540 .786 .549 & 11.217 .741 .311 .905 & - \\
\hline 2014 & 11.539 .505 .689 .891 & 12.045 .847 .341 .692 & 0,85 \\
\hline 2015 & 11.694 .163 .000 .000 & 12.149 .422 .484 .500 & 5,96 \\
\hline 2016 & 12.551 .166 .051 .800 & 12.874 .631 .946 .619 & 14,43 \\
\hline 2017 & 14.448 .900 .907 .863 & 14.733 .699 .981 .655 & 2,37 \\
\hline 2018 & 14.622 .475 .324 .280 & 15.084 .003 .946 .127 & 13,39 \\
\hline 2019 & 15.523 .728 .692 .158 & 17.104 .324 .024 .413 & \\
\hline
\end{tabular}

Sumber : BPS Provinsi Aceh, Provinsi Aceh Dalam Angka, 2021

Tabel 1menunjukkan bahwa anggaran Belanja Daerah di Provinsi Aceh mengalami peningkatan setiap tahunnya dan begitu juga dengan realisasi Belanja Daerah di Provinsi Aceh. Namun anggaran Belanja Daerah di Provinsi Aceh mengalami defisit terus menerus selama 7 tahun dari tahun 2013 sampai 2019. Apabila APBD mengalami defisit, defisit tersebut dapat dibiayai dengan penerimaan pembiayaan, misalnya Sisa Lebih Perhitungan Anggaran (SiLPA) tahun sebelumnya, penggunaan cadangan, penerimaan dari pinjaman, hasil penjualan kekayaan daerah yang dipisahkan, dan penerimaan kembali pemberian pinjaman atau penerimaan piutang. Dilihat dari tabel diatas realisasi Belanja Daerah tertinggi di Provinsi Aceh terjadi pada tahun 2019 yaitu sebesar Rp. 17.104.324.024.413 dengan perkembangan dari tahun sebelumnya sebesar $13,39 \%$. Namun perkembangan terbesar terjadi pada tahun 2017 sebesar 14,43\%, dan perkembangan realisasi Belanja Daerah terkecil Provinsi Aceh dari tahun sebelumnya terjadi pada tahun 2015 sebesar $0,85 \%$.

Untuk menyeimbangkan ketimpangan sumber pendanaan antar pusat dan daerah, maka ditetapkan transfer dana perimbangan salah satunya yaitu Dana Alokasi Umum (DAU). Ada dua faktor utama yang menentukan besarnya transfer Dana Alokasi Umum (DAU) dari pemerintah pusat ke pemerintah daerah. Faktor pertama adalah kebutuhan daerah (needs), faktor kedua adalah kemampuan finansial daerah yang adalah kemampuan dasar dalam membiayai Belanja Daerah yang berasal dari Pendapatan Asli Daerah (PAD) dan Dana Alokasi Umum (DAU) (Kurnia, 2013).

Permasalahan yang terjadi saat ini, pemerintah daerah terlalu bergantung pada Dana Alokasi Umum (DAU) untuk membiayai belanja modal dan pembangunan tanpa mengoptimalkan potensi yang dimiliki daerah. Disaat Dana Alokasi Umum (DAU) yang diperoleh besar, maka pemerintah daerah akan berusaha agar ditahun yang akan datang tetap memperoleh Dana Alokasi Umum (DAU) dengan nominal yang sama. Menurut Afrizawati (2012) proporsi Dana Alokasi Umum (DAU) terhadap penerimaan daerah masih yang 
tertinggi dibandingkan dengan penerimaan daerah yang lain, termasuk Pendapatan Asli Daerah (PAD).

Hal ini terlihat indikasi kuat perilaku belanja daerah sangat dipengaruhi sumber penerimaan dana berupa dana transfer yaitu Dana Alokasi Umum (DAU) sehingga akan melemahkan kemampuan daerah dalam membiayai kebutuhan sendiri. Berikut ini merupakan ringkasan anggaran dan realisasi Dana Alokasi Umum (DAU) Pemerintah Daerah Provinsi Aceh tahun 2013 sampai 2019.

\section{Tabel 2. Anggaran dan Realisasi Dana Alokasi Umum (DAU)} Provinsi Aceh Tahun 2013-2019

\begin{tabular}{cccc}
\hline Tahun & Anggaran (Rupiah) & Realisasi (Rupiah) & Perkembangan (\%) \\
\hline 2013 & 1.092 .445 .518 .000 & 1.092 .445 .518 .000 & - \\
\hline 2014 & 1.201 .612 .787 .000 & 1.201 .612 .787 .000 & 9,99 \\
\hline 2015 & 1.263 .870 .989 .000 & 1.237 .894 .986 .000 & 3,01 \\
\hline 2016 & 1.263 .870 .989 .000 & 1.263 .870 .989 .000 & 2,09 \\
\hline 2017 & 2.060 .263 .235 .000 & 2.060 .263 .235 .000 & 63,01 \\
\hline 2018 & 2.060 .263 .235 .000 & 2.060 .263 .235 .000 & 0 \\
\hline 2019 & 2.126 .619 .991 .000 & 2.322 .266 .506 .000 & 12,71 \\
\hline
\end{tabular}

Sumber : BPS Provinsi Aceh, Provinsi Aceh Dalam Angka, 2021

Tabel 2 menunjukkan bahwa jumlah transfer Dana Alokasi Umum (DAU) dari pemerintah pusat ke pemerintah daerah Provinsi Aceh terus mengalami peningkatan. Terlihat di tahun 2014 terjadi peningkatan dari tahun sebelumnya yaitu tahun 2013 sebesar Rp. 1.092.445.518.000. Di tahun 2015 dan 2016 DAU Provinsi Aceh mencapai Rp. 1.263.870.989.000. Pada tahun 2017 dan 2018 DAU Provinsi Aceh juga terus meningkat menjadi Rp. 2.060.263.235.000. Begitu juga pada tahun 2019 DAU Provinsi Aceh mengalami terus peningkatan sebesar Rp. 2.126.619.991.000. Hampir setiap tahunnya DAU di Provinsi Aceh terus mengalami peningkatan, begitu juga dengan realisasi DAU di Provinsi Aceh. Realisasi DAU tertinggi di Provinsi Aceh terjadi pada tahun 2019 yaitu sebesar Rp. 2.322.266.506.000 dengan perkembangan dari tahun sebelumnya sebesar 12,71\%. Namun perkembangan terbesar terjadi pada tahun 2017 sebesar 63,01\%, dan perkembangan realisasi DAU terkecil Provinsi Aceh dari tahun sebelumnya terjadi pada tahun 2018 sebesar 0\%.

Pendapatan Asli Daerah (PAD) merupakan sumber pendapatan kabupaten/kota yang murni digali oleh daerah. Besar kecilnya PAD mencerminkan kemandirian suatu daerah dalam membiayai pelaksanaan pembangunan didaerahnya. Semakin besar Pendapatan Asli Daerah (PAD) pada suatu daerah, maka daerah tersebut dapat dikatakan semakin mandiri dalam pelaksanaan pembangunan didaerahnya dan diharapkan dimasa yang akan datang peran Pendapatan Asli Daerah (PAD) dalam membiayai kegiatan pemerintahan dan pembangunan didaerah akan semakin meningkat (Febriana \& Praptoyo, 2015).

Untuk meningkatkan pelayanan publik, Pemerintah Daerah mengalokasikan Pendapatan Asli Daerah dengan melakukan belanja untuk kepentingan investasi yang direalisasikan melalui Belanja Modal. Pada kasus pemerintah daerah kabupaten/kota di Indonesia, data menunjukkan proporsi Pendapatan Asli Daerah (PAD) hanya mampu 
membiayai belanja pemerintah daerah paling tinggi sebesar 20 persen (Kuncoro, 2007). Berikut ini merupakan ringkasan anggaran dan realisasi Pendapatan Asli Daerah (PAD) Pemerintah Daerah Provinsi Aceh tahun 2013 sampai 2019.

Tabel 3 menunjukkan bahwa Pendapatan Asli Daerah (PAD) Provinsi Aceh mengalami terus peningkatan dari tahun 2013-2019. Dimana pada tahun 2013 anggaran PAD Provinsi Aceh mencapai Rp. 1.167.694.484.330 dengan realisasinya sebesar Rp. 1.309.622.500.492. Pada tahun 2014, anggaran PAD Provinsi Aceh meningkat menjadi Rp. 1.849.214.279.799 dengan realisasinya sebesar Rp. 1.731.130.839.637. Di tahun 2015 dan 2016, anggaran PAD Provinsi Aceh kembali meningkat dengan besaran yang sama yaitu sebesar Rp. 2.057.481.533.300 namun dengan realisasi yang berbeda yaitu di tahun 2015 sebesar Rp. 1.972.049.032.901 dan di tahun 2016 sebesar Rp. 2.060.180.945.551. Pada tahun 2017 anggaran PAD Provinsi Aceh kembali meningkat menjadi Rp. 2.247.274.970.755 dan realisasinya juga meningkat mencapai Rp. 2.276.305.568.813. PAD Provinsi Aceh di tahun 2018 kembali meningkat menjadi Rp. 2.324.662.431.200, dengan realisasinya mencapai Rp. 2.359.385.393.645. Begitu juga di tahun 2019 PAD Provinsi Aceh terus meningkat mencapai Rp. 2.589.284.044.683 dan realisasinya juga meningkat sebesar Rp. 2.698.912.471.144.

Tabel 3. Anggaran dan Realisasi Pendapatan Asli Daerah (PAD) Provinsi Aceh Tahun 2013-2019

\begin{tabular}{cccc}
\hline Tahun & Anggaran (Rupiah) & Realisasi (Rupiah) & Perkembangan (\%) \\
\hline 2013 & 1.167 .694 .484 .330 & 1.309 .622 .500 .492 & - \\
\hline 2014 & 1.849 .214 .279 .799 & 1.731 .130 .839 .637 & 32,18 \\
\hline 2015 & 2.057 .481 .533 .300 & 1.972 .049 .032 .901 & 13,91 \\
\hline 2016 & 2.057 .481 .533 .300 & 2.060 .180 .945 .551 & 4,46 \\
\hline 2017 & 2.247 .274 .970 .755 & 2.276 .305 .568 .813 & 10,49 \\
\hline 2018 & 2.324 .662 .431 .200 & 2.359 .385 .393 .645 & 3,64 \\
\hline 2019 & 2.589 .284 .044 .683 & 2.698 .912 .471 .144 & 14,39 \\
\hline
\end{tabular}

Realisasi PAD tertinggi di Provinsi Aceh terjadi pada tahun 2019 yaitu sebesar Rp. 2.698.912.471.144 dengan perkembangan dari tahun sebelumnya sebesar 14,39\%. Namun perkembangan terbesar terjadi pada tahun 2014 sebesar 32,18\%, dan perkembangan realisasi DAU terkecil Provinsi Aceh dari tahun sebelumnya terjadi pada tahun 2018 sebesar 3,64\%. Peningkatan Pendapatan Asli Daerah (PAD) Provinsi Aceh dipengaruhi oleh seberapa banyak penerimaan dana yang diterima oleh Provinsi Aceh, yang bersumber dari pajak daerah, retribusi daerah, hasil pengelolaan kekayaan yang dipisahkan, dan lain-lain pendapatan asli daerah yang sah.

Berdasarkan data-data menunjukkan bahwa kemandirian Provinsi Aceh dalam bentuk penerimaan Pendapatan Asli Daerah (PAD) sudah sangat baik, karena sumber penerimaan Pendapatan Asli Daerah (PAD) Provinisi Aceh lebih besar dari Dana Alokasi Umum (DAU). Provinsi Aceh sudah sangat baik dalam mengoptimalkan sumber-sumber penerimaan di daerahnya. 
Pada penelitian yang dilakukan oleh Maimunah (2006) diketahui bahwa tidak terdapat perbedaan terjadinya flypaper effect baik pada daerah yang PAD nya tinggi maupun pada daerah yang PAD nya rendah, dengan kata lain, flypaper effect tidak hanya terjadi pada daerah miskin PAD, namun juga daerah kaya PAD.

\section{KERANGKA TEORITIS DAN PENGEMBANGAN HIPOTESIS Belanja Daerah}

Belanja Daerah adalah seluruh pendapatan daerah yang diperoleh baik dari sumber kekayaan daerahnya itu sendiri maupun bantuan dana transfer dari pemerintah pusat yang digunakan untuk membiayai seluruh pengeluaran daerah itu. Pendapatan daerah itu bisa berupa Pendapatan Asli Daerah (PAD), dana perimbangan dan lain-lain pendapatan daerah yang sah (Adiputra, 2014).

Menurut UU No. 32 Tahun 2004 tentang Pemerintah Daerah, belanja daerah adalah semua kewajiban daerah yang diakui sebagai pengurang nilai kekayaan bersih dalam periode anggaran yang bersangkutan. Belanja Daerah difokuskan untuk mendanai urusan pemerintah wajib yang berkaitan dengan pelayanan dasar yang ditetapkan sesuai standar pelayanan minimal dengan berpedoman pada standar teknis dan standar harga satuan regional sesuai dengan peraturan perundang-undangan. Belanja daerah sebagaimana yang tertera didalam Peraturan Menteri Dalam Negeri Nomor 13 Tahun 2006 tentang Pedoman dasar Pengelolaan Keuangan Daerah pasal 31 ayat (1) menyebutkan bahwa belanja daerah dipergunakan dalam rangka mendanai pelaksanaan urusan pemerintah yang menjadi kewenangan provinsi atau kabupaten/kota yang terdiri dari urusan wajib, urusan pilihan dan urusan yang penanganannya dalam bagian atau bidang tertentu yang dapat dilaksanakan bersama antara pemerintah pusat dan pemerintah daerah atau antar sesama pemerintah daerah lainnya yang ditetapkan berdasarkan peraturan perundang-undangan.

\section{Dana Alokasi Umum}

Menurut UU No. 33 Tahun 2004 Dana Alokasi Umum atau disebut dengan DAU adalah dana yang bersumber dari pendapatan APBN yang dialokasikan dengan tujuan pemerataan kemampuan keuangan antar daerah untuk mendanai kebutuhan keuangan daerah dalam rangka pelaksanaan desentralisasi. Sumber penerimaan daerah dalam konteks otonomi dan desentralisasi untuk saat ini masih lebih didominasi oleh bantuan transfer dari pemerintah pusat baik brupa Dana Alokasi Umum (DAU), Dana Alokasi Khusus (DAK), dan bagi hasil, sedangkan porsi sumber PAD masih relatif kecil (Mardiasmo, 2004).

Menurut Halim (2016) menjelaskan bahwa Dana alokasi umum adalah dana transfer yang bersifat block grant, sehingga pemerintah daerah mempunyai keleluasaan dalam menggunakan DAU sesuai dengan kebutuhan dan program masing-masing daerah.

Alokasi DAU bagi daerah yang potensi fiskalnya besar namun kebutuhan fiskalnya kecil akan memperoleh alokasi Dana Alokasi Umum yang relatif kecil. Sebaliknya daerah yang memiliki potensi fiskalnya kecil namun kebutuhan fiskalnya besar akan memperoleh pengalokasian Dana alokasi umum yang relatif besar. Dengan maksud dan tujuan melihat kemampuan APBD dalam membiayai kebutuhan-kebutuhan daerahnya dalam rangka 
pembangunan daerah yang dicerminkan dari penerimaan umum APBD dikurangi dengan belanja pegawai (Halim, 2009).

Adapun cara menghitung dana alokasi umum menurut ketentuan dalam Undang-Undang Nomor 33 Tahun 2004 adalah sebagai berikut:

a. Dana Alokasi Umum (DAU) ditetapkan sekurang-kurangnya 26\% dari penerimaan dalam negeri yang ditetapkan dalam APBN

b. Dana Alokasi umum (DAU) untuk daerah provinsi dan untuk daerah kabupaten/kota ditetapkan masing-masing 10\% dan 90\% dari dana alokasi umum sebagaimana ditetapkan diatas

c. Dana Alokasi Umum (DAU) untuk suatu daerah kabupaten/kota tertentu ditetapkan berdasarkan perkalian jumlah dana alokasi umum untuk daerah kabupaten/kota yang bersangkutan.

d. Porsi daerah kabupaten/kota sebagaimana dimaksud diatas merupakan proporsi bobot daerah kabupaten/kota yang bersangkutan terhadap jumlah bobot semua daerah kabupaten/kota diseluruh Indonesia.

\section{Pendapatan Asli Daerah}

Pendapatan asli daerah (PAD) adalah penerimaan yang diperoleh dari sumber kekayaan dalam wilayahnya sendiri, semakin tinggi peranan PAD dalam struktur keuangan daerah, maka semakin tinggi pula kemampuan keuangan yang dimiliki oleh daerah untuk memenuhi kebutuhan pembangunan daerahnya (Carunia, 2017).

Pendapatan asli daerah (PAD) bersumber dari pendapatan yaitu seperti pajak daerah, retribusi daerah, hasil pengelolaan kekayaan yang dipisahkan, lain-lain pendapatan asli daerah yang sah. Pendapatan asli daerah dikatakan baik untuk memenuhi pembiayaan pembangunan daerahnya apabila pencapaian presentasenya melebihi $70 \%$ dari total penerimaan PAD (Carunia, 2017).

Pendapatan Asli Daerah (PAD) bersumber dari :

1. Pajak Daerah

Undang-undang Nomor 28 Tahun 2009 tentang Pajak dan Retribusi Daerah menjelaskan bahwa Pajak Daerah, yang selanjutnya disebut Pajak, adalah kontribusi wajib kepada daerah yang terhutang oleh orang pribadi atau badan yang bersifat memaksa berdasarkan undang- undang, dengan tidak memperoleh imbalan secara langsung dan digunakan untuk keperluan daerah bagi sebesar-besarnya kemakmuran rakyat.

2. Retribusi Daerah

Menurut Mardiasmo (2011) menyebutkan bahwa Retribusi Daerah adalah pungutan Daerah sebagai pembayaran atas jasa atau pemberian izin tertentu yang telah disediakan atau diberikan oleh Pemerintah Daerah untuk kepentingan orang pribadi atau suatu badan.

3. Hasil pengelolaan kekayaan daerah yang dipisahkan

Hasil pengelolaan kekayaan daerah yang dipisahkan yaitu merupakan susunan kegiatan dan tindakan yang meliputi perencanaan, penentuan kebutuhan, pengendalian, pemeliharaan, pemanfaatan, pengamanan, dan perubahan status hokum serta penatausahaannya. Hasil pengelolaan kekayaan yang dipisahkan meliputi bagian laba atas 
penyertaan sebagian modal pada perusahaan milik daerah dan bagian laba atas penyertaan modal pada perusahaan milik negara.

4. Lain-lain Pendapatan Asli Daerah yang sah

Menurut undang-undang nomor 25 tahun 1999 menyebutkan bahwa pendapatan asli daerah yang sah adalah hasil daerah yang didapat dari usaha diluar kegiatan dan pelaksanaan tugas daerah (undang-undang nomor 25 tahun 1999). Berdasarkan Permendagri Nomor 13 Tahun 2006, yang dimaksud dengan lain-lain pendapatan asli daerah, antara lain;

a. Hasil penjualan kekayaan daerah yang tidak dipisahkan

b. Jasa giro

c. Pendapatan bunga

d. Penerimaan atas tuntutan ganti rugi kerugian daerah

e. Penerimaan komisi / potongan ataupun bentuk lain sebagai akibat dari penjualan dan / atau pengadaan barang dan jasa oleh daerah

f. Penerimaan keuntungan dari selisih nilai tukar rupiah terhadap mata uang asing

g. Pendapatan atas keterlambatan pelaksanaan pekerjaan

h. Pendapatan denda pajak

i. Pendapatan denda distribusi

j. Pendapatan hasil eksekusi atas jaminan

k. Pendapatan dari pengambilan

1. Fasilitas sosial dan umum

m. Pendapatan dari penyelenggaraan pendidikan dan pelatihan

Pendapatan dari angsuran / cicilan penjualan

\section{Flypaper Effect}

Flypaper Effect merupakan suatu kondisi yang terjadi dimana pemerintah daerah merespon (belanja) lebih banyak (lebih boros) dengan menggunakan dana transfer (grants) yang bersumber dari DAU dari pada menggunakan kemampuan daerah sendiri, yang bersumber dari PAD. (Maimunah, 2006).

Menurut Dougan dan Kenyon (dalam Ndadari dan Adi, 2008) mengatakan bahwa Flypaper Effect merupakan suatu keganjilan yang dimana kecendrungan dari dana bantuan (transfer) akan meningkatkan belanja publik yang besar dibandingkan dengan pertambahan pendapatan yang diperoleh masyarakat.

Dalam hal ini dapat disimpulkan bahwa Flypaper Effect adalah suatu kondisi yang terjadi pada saat pemerintah daerah merespon lebih banyak dengan menggunakan dana transfer (DAU) dari pada menggunakan pendapatan asli daerah. Dengan begitu Fenomena Flypaper Effect membawa implikasi lebih luas bahwa transfer akan meningkatkan Belanja Daerah yang lebih besar daripada penerimaan daerah itu sendiri.

Untuk melihat apakah terjadi Flypaper Effect atau tidak dapat dilihat dari perbandingan antara koefisien Dana Alokasi Umum dan koefisien Pendapatan Asli Daerah, atau dapat di fungsikan jika:

$\beta 1>\beta 2$ berarti $\frac{\beta 1}{\beta 2}>1$ maka terjadi flypaper effect (Tresch, 2002) 


\section{METODE PENELITIAN}

\section{Ruang Lingkup dan Lokasi Penelitian}

Penelitian dilakukan di Provinsi Aceh dengan ruang lingkup penelitian merupakan kajian dari Ekonomi Publik. Penelitian ini menganalisis Tentang Flypaper Effect pada Dana Alokasi Umum dan Pendapatan Asli Daerah terhadap Belanja Daerah di Provinsi Aceh. Penelitian ini dilakukan pada bulan desember 2020 sampai dengan bulan juni 2021.

\section{Metode Analisis Data}

Penelitian ini menggunakan pendekatan kuantitatif yang berupa angka atau bilangan yang diolah dengan menggunakan program Microsoft Excel dan Eviews. Metode analisis data yang digunakan dalam penelitian ini yaitu:

1. Analisis Regresi Linier Berganda (Multiple Regression)

Teknik analisis regresi yang digunakan dalam penelitian ini adalah analisis regresi linier berganda digunakan untuk melihat pengaruh seluruh variabel tersebut secara serentak, hasil dari uji ini akan menunjukkan apakah ada pengaruh antara Dana Alokasi Umum, Pendapatan Asli Daerah, terhadap Belanja Daerah (Elisabeth, 2018). Persamaan regresinya adalah sebagai berikut (Gozhali, 2016):

$$
\begin{aligned}
& Y=\alpha+\beta_{1} X_{1}+\beta_{2} X_{2}+e \\
& \text { Dimana : } \\
& \mathrm{Y} \quad=\text { Belanja Daerah } \\
& \alpha=\text { Konstanta } \\
& \beta=\text { Koefisien Regresi } \\
& \mathrm{X}_{1} \quad=\text { Dana Alokasi Umum } \\
& \mathrm{X}_{2} \quad=\text { Pendapatan Asli Daerah } \\
& \mathrm{e}=\operatorname{Error}(\text { Faktor pengganggu/ residual) }
\end{aligned}
$$

\section{Analisis Flypaper Effect}

Untuk menguji fenomena flypaper effect akan dilakukan serangkaian pengujian setelah tahap pengujian pengaruh variabel, tahap-tahap tersebut antara lain, tahap pertama membandingkan nilai koefisien PAD dengan nilai koefisien DAU yang berpengaruh signifikan terhadap Belanja Daerah.

Untuk melihat apakah terjadi flypaper effect atau tidak dapat dilihat dari perbandingan antara koefisien Dana Alokasi Umum dan koefisien Pendapatan Asli Daerah, atau dapat difungsikan jika

$$
\beta 1>\beta 2 \text { berarti } \frac{\beta 1}{\beta 2}>1 \text { maka terjadi flypaper effect } \text { (Tresch, 2002) }
$$

Dimana :

$\beta 1=$ Koefisien Dana Alokasi Umum

$\beta 2=$ Koefisien Pendapatan Asli Daerah

\section{HASIL PENELITIAN DAN PEMBAHASAN}

\section{Analisis Model Regresi}

Untuk mengetahui besarnya pengaruh Dana Alokasi Umum dan Pendapatan Asli Daerah terhadap Belanja Daerah serta kemungkinan terjadinya Flypaper Effect pada laporan 
keuangan Provinsi Aceh dapat dilihat dari hasil regresi linear berganda berupa uji parsial (Uji t), uji simultan (Uji F), dan koefisien determinan $\left(\mathrm{R}^{2}\right)$ yang pengolahannya dibantu dengan menggunakan Eviews dengan hasil sebagai berikut :

Tabel IV-4

\section{Hasil Perhitungan Dengan Eviews}

Dependent Variable: Y

Method: Least Squares

Date: 03/31/21 Time: 22:06

Sample: 20102020

Included observations: 11

\begin{tabular}{lllll}
\hline \hline Variable & Coefficient & Std. Error & t-Statistic & Prob. \\
\hline \hline C & $3.88 \mathrm{E}+12$ & $4.82 \mathrm{E}+11$ & 8.044973 & 0.0000 \\
X1 & 2.046374 & 0.853752 & 2.396919 & 0.0434 \\
X2 & 3.149945 & 0.726134 & 4.337966 & 0.0025 \\
\hline \hline R-squared & 0.978390 & Mean dependent var & $1.24 \mathrm{E}+13$ \\
Adjusted R-squared & 0.972987 & S.D. dependent var & $3.50 \mathrm{E}+12$ \\
S.E. of regression & $5.76 \mathrm{E}+11$ & Akaike info criterion & 57.22222 \\
Sum squared resid & $2.65 \mathrm{E}+24$ & Schwarz criterion & 57.33074 \\
Log likelihood & -311.7222 & Hannan-Quinn criter. & 57.15382 \\
F-statistic & 181.0992 & Durbin-Watson stat & 1.321931 \\
Prob(F-statistic) & 0.000000 & & \\
\hline \hline
\end{tabular}

Sumber : Data diolah, 2021

Berdasarkan hasil perhitungan regresi linear berganda, maka diperoleh persamaan sebagai berikut :

$\log \mathrm{Y}=3,88+2,0463 \log \mathrm{X} 1+3,1499 \log \mathrm{X} 2$

a. Nilai konstanta sebesar 3,88 artinya apabila nilai Dana Alokasi Umum dan Pendapatan Asli Daerah tidak mengalami perubahan, maka Belanja Daerah Provinsi Aceh sebesar 3,88 satuan.

b. Nilai koefisien Dana Alokasi Umum (X1) sebesar 2,0463 artinya Dana Alokasi Umum memiliki pengaruh positif terhadap Belanja Daerah, yaitu apabila Dana Alokasi Umum meningkat 1 satuan maka Belanja Daerah akan meningkat 2,0463 satuan.

c. Nilai koefisien Pendapatan Asli Daerah (X2) sebesar 3,1499 artinya Pendapatan Asli Daerah memiliki pengaruh positif terhadap Belanja Daerah, yaitu apabila Pendapatan Asli Daerah meningkat 1 satuan maka Belanja Daerah akan meningkat 3,1499 satuan.

\section{Pembuktian Hipotesis}

Hasil pengujian hipotesis dalam penelitian ini dibedakan menjadi dua yaitu:

1) Hasil Uji t 
Uji t dilakukan untuk membuktikan secara parsial apakah terdapat pengaruh masing- masing variabel independen terhadap variabel dependen. Berdasarkan tabel IV-4 dapat dilihat bahwa:

- Variabel Dana Alokasi Umum memiliki thitung sebesar 2,396 dengan t sig sebesar 0,0434. Karena nilai t sig 0,0434<0,05 maka dapat dinyatakan bahwa Dana Alokasi Umum berpengaruh signifikan terhadap Belanja Daerah di Provinsi Aceh sehingga hipotesis diterima atau terbukti kebenarannya.

- Variabel Pendapatan Asli Daerah memiliki thitung sebesar 4.337 dengan t sig sebesar 0,0025. Karena nilai t sig 0,0025 < 0,05 maka dapat dinyatakan bahwa Pendapatan Asli Daerah berpengaruh signifikan terhadap Belanja Daerah di Provinsi Aceh sehingga hipotesis diterima atau terbukti kebenarannya.

2) Hasil Uji F

Uji F untuk menguji signifikansi sejauh mana variabel-variabel independen secara simultan yang digunakan mampu menjelaskan variabel dependen. Berdasarkan tabel IV-4 dapat diketahui nilai probabilitas sebesar 0,0000 karena nilai probabilitas lebih kecil dibandingkan tingkat signifikansi yakni $0,05(0,00<0,05)$ maka pengaruh simultan dari variabel bebas Dana Alokasi Umum dan Pendapatan Asli Daerah terhadap Belanja Daerah di Provinsi Aceh adalah signifikan, sehingga hipotesis diterima atau terbukti kebenarannya.

\section{Hasil Analisis Koefisien Determinasi $\left(\mathbf{R}^{2}\right)$}

Berdasarkan tabel IV-4 diketahui nilai koefisien determinasi atau R square adalah sebesar 0,9783. Besarnya angka koefisien determinasi ( $\mathrm{R}$ square) adalah 0,9783 atau sama dengan 97,83\%. Angka tersebut mengandung arti bahwa variabel Dana Alokasi Umum (X1) dan Pendapatan Asli Daerah (X2) secara simultan berpengaruh terhadap Belanja Daerah. Sedangkan sisanya 2,17\% dijelaskan oleh variabel lain yang tidak diteliti dalam penelitian ini.

\section{Hasil Analisis Flypaper Effect}

Dapat dilihat pada tabel IV-4 koefisien Dana Alokasi Umum sebesar 2,0463 lebih besar dari koefisien Pendapatan Asli Daerah sebesar 3,1499 dimana memiliki arti bahwa tidak terjadi flypaper effect pada Belanja Daerah di Provinsi Aceh atau dapat difungsikan jika:

$\beta 1>\beta 2$ berarti $\frac{\beta 1}{\beta 2}>1$ maka terjadi flypaper effect (Tresch, 2002)

Dimana :

$\beta 1=$ Koefisien Dana Alokasi Umum

$\beta 2=$ Koefisien Pendapatan Asli Daerah

Sedangkan :

$2,0463<3,1499$ berarti $\frac{2,0463}{3,1499}=0,65<1$ maka tidak terjadi flypaper effect

Penelitian ini membuktikan bahwa besarnya Belanja Daerah dipengaruhi oleh jumlah Pendapatan Asli Daerah (PAD) yang diperoleh dari pendapatan daerah Provinsi Aceh itu sendiri. Hal ini menunjukkan bahwa tingkat ketergantungan Pemerintah Provinsi Aceh terhadap pemerintah pusat tergolong rendah dan sudah mandiri. Pemerintah Provinsi Aceh tetap harus melakukan langkah-langkah strategis dalam menggali terus potensi Pendapatan Asli Daerah (PAD) agar Provinsi Aceh bisa mempertahankan tingkat kemandirian tersebut. Hal ini membuktikan bahwa Provinsi Aceh dapat dikatakan mampu membiayai pengeluaran daerahnya dengan kemampuan fiskalnya. 


\section{KESIMPULAN, KETERBATASAN DAN SARAN}

Berdasarkan hasil analisis disimpulkan bahwa Dana Alokasi Umum, Pendapatan Asli Daerah berpengaruh positif dan signifikan terhadap Belanja Daerah di Provinsi Aceh, baik secara parsial maupun simultan. Selanjutnya pada penelitian ini dapat disimpulkan pula tidak ada terjadi flypaper effect pada Belanja Daerah di Provinsi Aceh.

Rekomendasi bagi pemerintah Provinsi Aceh ke depannya, agar terus menggali potensi daerah dan melakukan langkah-langkah strategis, sehingga bisa mempertahankan tingkat kemandirian di Provinsi Aceh. Pemerintah Provinsi Aceh harus memahami bahwa Dana Alokasi Umum tersebut hanyalah sebagai pemicu kemandirian suatu daerah sebagai langkah awal keberhasilan otonomi.

Penelitian ini masih jauh sempurna, untuk itu disaran untuk penelitian selanjutnya sebaiknya periode waktu/tahun ditambah sehingga menghasilkan informasi yang lebih mendukung. Disamping itu variabel belanja daerah dibuat menjadi beberapa variabel sesuai dengan rincian atau item belanja daerah sehingga nantinya diharapkan kesimpulan yang diperoleh lebih sempurna.

\section{DAFTAR PUSTAKA}

Adiputra, I Made Pradana. 2014. Flypaper Effect Pada Dana Alokasi Umum (Dau) Dan Pendapatan Asli Daerah (Pad) Terhadap Belanja Daerah Di Kabupaten Karangasem. Jurnal Ilmiah Akuntansi dan Humanika. Volume 3, Nomor 2, Universitas Pendidikan Ganesha, Juni 2014.

Al Khoiri, Rifki Hasan. 2015. Flypaper Effect dan Belanja Daerah di Provinsi Jawa Barat. Jurnal Ilmu Ekonomi Volume 4, Nomor 2, Oktober 2015.

Amalia, Nor, Nordiansyah. 2015. Flypaper Effect Pada Pendapatan Asli Daerah (PAD), Dana Alokasi Umum (DAU), dan Dana Alokasi Khusus (DAK) terhadap Belanja Daerah pada Pemerintah Kabupaten/Kota di Provinsi Kalimantan Selatan (2009 - 2013). Jurnal Akuntansi dan Bisnis. Vol. 15, No. 1, Februari 2015: 1-12. Universitas Lambung Mangkurat 2015.

Ardanareswari, Laut, Destiningsih. 2019. Fenomena Flypaper Effect Pada PAD, DAU Dan DBH Serta Pengaruhnya Terhadap Belanja Daerah Di Pulau Jawa Tahun 2013-2017. Jurnal Ekonomi. Vol. 1 No. 4. Universitas Tidar, Magelang 2019.

Elisabeth. 2018. Pengaruh Pendapatan Asli Daerah, Dana Alokasi Umum, Dana Alokasi Khusus, dan Dana Bagi Hasil terhadap Belanja Daerah serta Analisis Flypaper Effect pada Kabupaten dan Kota di Provinsi Jawa Barat. Skripsi. Universitas Sanata Dharma Yogyakarta.

Haryanto, Aliferiana Irsyadhea Putri. 2019. Flypaper Effect pada Dana Alokasi Umum dan

Pendapatan Asli Daerah terhadap Belanja Daerah Kabupaten/Kota di Provinsi Jawa Tengah. Jurnal Akuntansi. Universitas Diponegoro. Volume 8, Nomor 2, Tahun 2019, Halaman 1-15.

Ikhwani, Naz'aina, Ratna. 2019. Flypaper Effect Pada Pengaruh Dana Alokasi Umum, Dana Alokasi Khusus dan Pendapatan Asli Daerah Terhadap Belanja Daerah 
Kabupaten/Kota Di Provinsi Aceh. Jurnal Manajemen Indonesia. Universitas Malikussaleh. Vol. 4, No. 2 Juli-Desember 2019.

Kusumadewi, Rahman. 2007. Flypaper Effect Pada Dana Alokasi Umum (DAU) dan Pendapatan Asli Daerah (PAD) Terhadap Belanja Daerah Pada Kabupaten/Kota Di Indonesia. Jurnal Ekonomi. Universitas Islam Indonesia. Vol. 11, No 1, Juni 2007: 67-80.

Mawarni, 2013. Pengaruh PAD dan DAU terhadap Belanja Modal serta dampaknya terhadap Pertumbuhan Ekonomi Daerah (Studi pada Kabupaten dan Kota di Aceh). Jurnal Akuntansi. Universitas Syiah Kuala. Vol 2, No 2, Hal 80-90.

Rahmah, 2019. Flypaper Effect Pada Dana Alokasi Umum (DAU) dan Pendapatan Asli Daerah (PAD) Terhadap Belanja Daerah Pada Kabupaten/Kota Di Indonesia. Skripsi. Universitas Islam Negeri Sunan Kalijaga.

Saputri, Muid. 2014. Flypaper Effect Pada Dana Alokasi Umum dan Pendapatan Asli Daerah Terhadap Belanja Daerah Pada Kabupaten/Kota Di Jawa Tengah Tahun 2011-2012. Jurnal Akuntansi. Universitas Diponegoro. Volume 3, Nomor 2 Semarang, 2014, hal $1-11$.

Sihombing, Wijaya. 2016. Flypaper Effect Pada Dana Alokasi Umum dan Pendapatan Asli Daerah Terhadap Belanja Daerah Di Provinsi Papua. Jurnal Akuntansi \& Keuangan Daerah. FEB Uncen. Volume 11, Nomor 1, mei 2016, hal 29-37.

Wulansari, Dessy Tri. 2015. Pengaruh Pendapatan Asli Daerah dan Dana Perimbangan terhadap Belanja Daerah serta Analisis Flypaper Effect. Skripsi. Universitas Muhammadiyah Surakarta. 